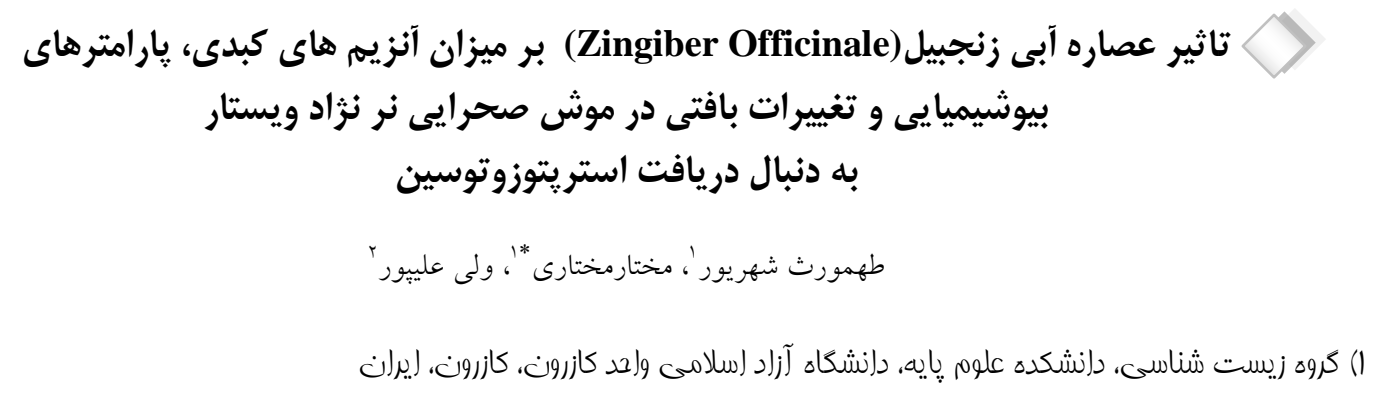

N) كروه بهد(شت محيط، دانشكده بهداشت محيط، دانشكاه علوم :زشكى 9 خدمات بهداشتى درمانى هرمزكان، هرمزكان، ليران.

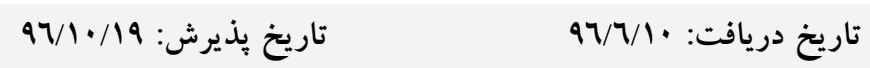

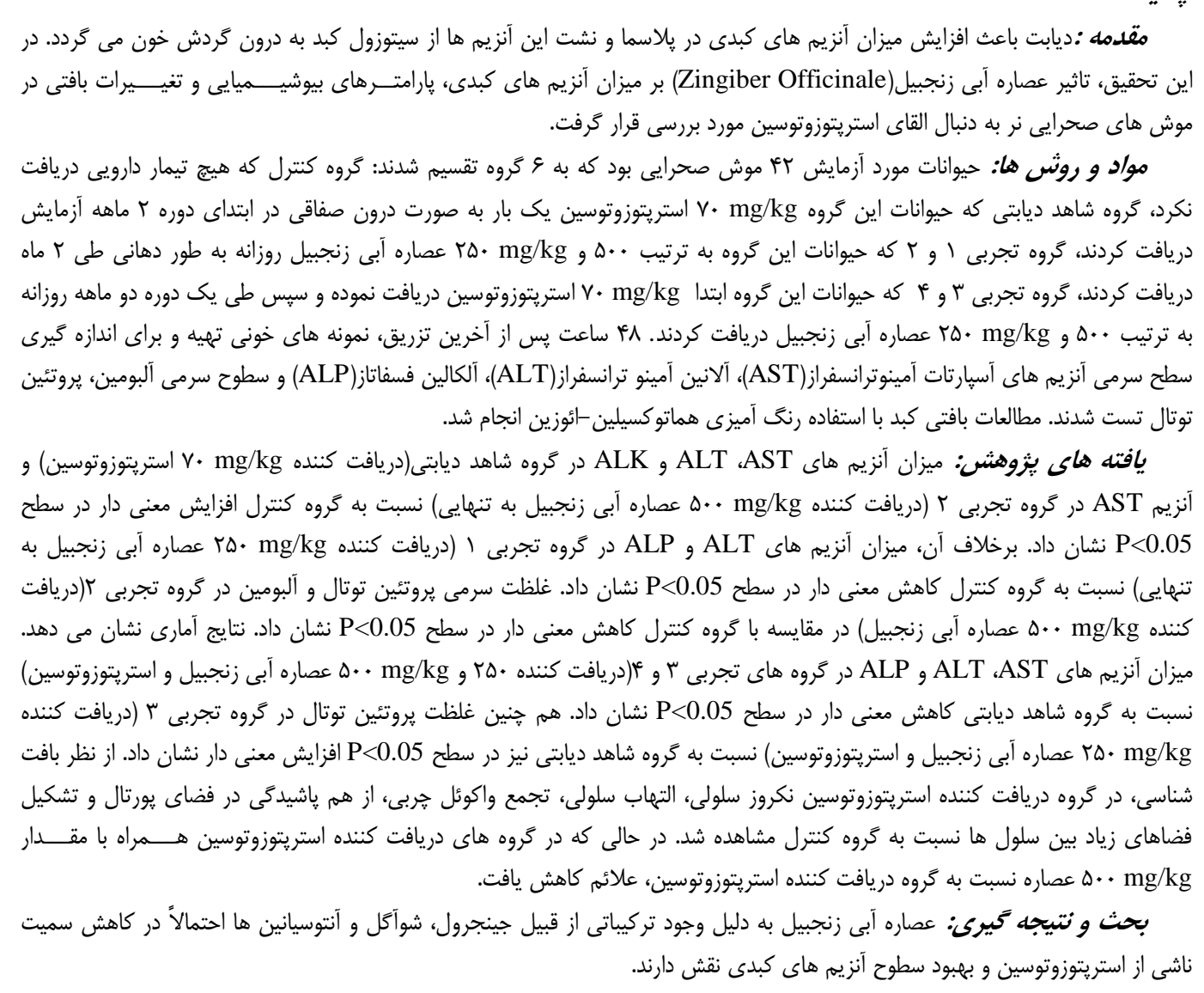

*ُنويسنده مسئول: گروه بهداشت محيط، دانشكده بهداشت محيط، دانشخاه علوم بزشكى و خدمات بهداشتى درمانى هرمز كان، هرمز كان، ايران Email:M.Mokhtari246@yahoo.com

Copyright (C) 2018 Journal of Ilam University of Medical Science. This is an open-access article distributed under the terms of the Creative Commons Attribution international 4.0 International License (https://creativecommons.org/licenses/by-nc/4.0/) which permits copy and redistribute the material, in any medium or format, provided the original work is properly cited. 
ترينوئيدها، سايونين ها و تـانن ها هــــتـند كه نقش

مهمى را در خصــــوصيـــــات طبى اين كَياه بر عهده

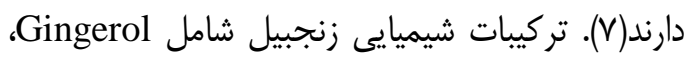

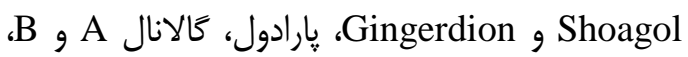

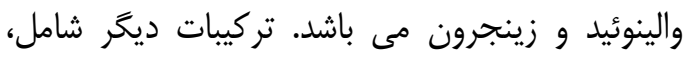

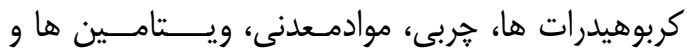
واكس ها مى باشد. ديخر اجزاء ريزوم شامل، روغن مون

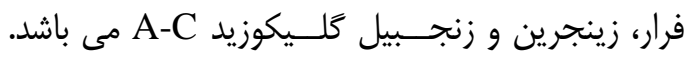
اثرات تازه زنجبيل به دليل جينجرول ها مى باشد كه

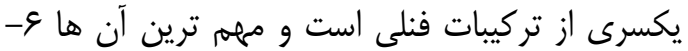
جينجرول مى باشد و اثرات زنجبيل خشك اند به دليل شوآكول ها است كه فرم دهيدراته شده جينجرول هات هاتئل

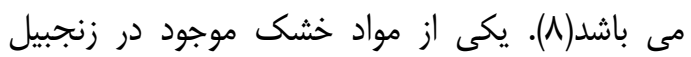
خشك، شوآكًل مى باشد. مطالعات نشان مى دهى دهد شوآكَول فرم هيدراته جينجرول مى باشد كه نقان

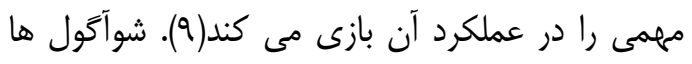
غلظت كلسيم درون سلولى را افزايش مى دهن دهند. برخى از تركيبات زنجبيل مــانند فنــوليك و والجينجرول،

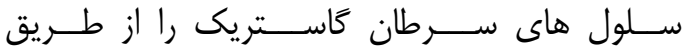

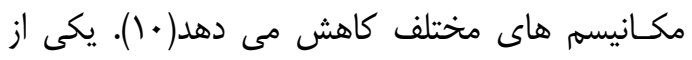

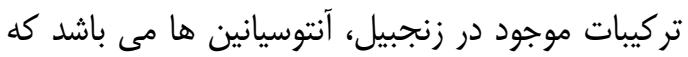
تركيبات آنتى اكسيدانى بسيار قدرتمندى هستند كه با

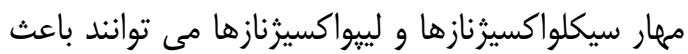
سركوب مسيرهاى مرتبط با درد شوند. اين تركيـبـات

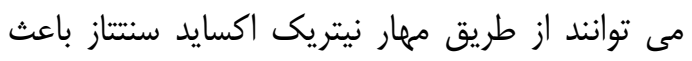
مهار مسيرهاى التهابى شده و اثرات ضد دردى خود را نشان مى دهد(1). مطالعات نشان مى دهد كه فعاليت

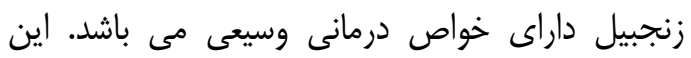

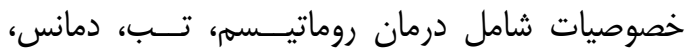
يرفشارى خون، استفراغ، يبوست، درد، عفونت، آسم، ديابت، بيمارى عصبى، درد قفسه سينه، تنظيم ايمنى،

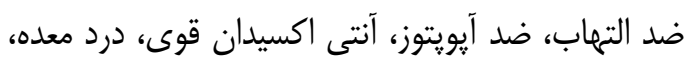

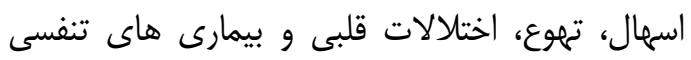
مى باشد. هم جنين زنجبيل داراى خصوصيات ضد إدات

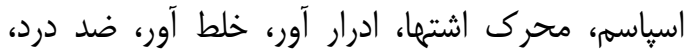
آرامش بخش، آنتى باكتريال، شل كننده عروق، شل ال

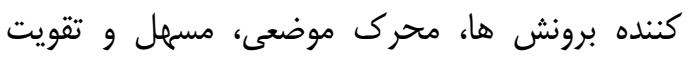

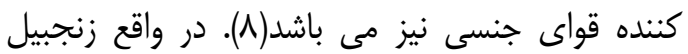

كبــــد نـــقش هاى مهمهــى را در فرآيندهاى فيزيولوزيكى از جمله متابوليسه، ترشح و ذخيره مواد بر عهده دارد. علاوه بر اين سم زدايى انواع داروها در كبد روى مى دهد. هياتيت حاد، مزمن و سيروز كبدى به اله دنبال اختلالات كبدى ايجاد مى شود(ا). در روند ديابت تغييراتى در كربوهيدرات ها، ليييدها، يروتئين ها

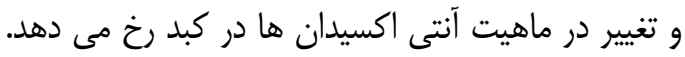
تغييرات بيوشيميايى و عملكرد غير طبيعى كبد كه شامل تغيير در كربوهيدرات ها، لييبدها، يروتئين ها و وبئي

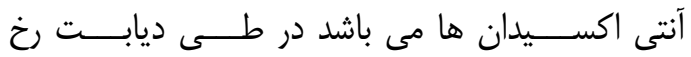
مى دهد(Y). استريتوزوتوسين(STZ) يك تركيب طبيعى است كه توسط باكترى استريتومايسن آكروموزنز توليد مى شود، اين تركيب خاصيت ضد باكتريايى قوى دارئ دارد و در درمان ســـلول هاى بــتاى پانكـــراس به كار

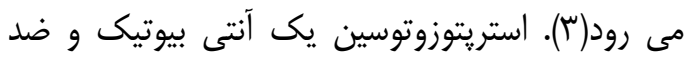
سرطان براى القاى ديابت نوع I است اين ماده،

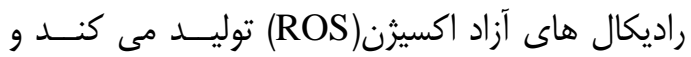

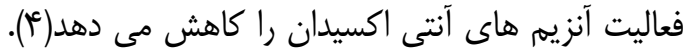
در ديابت القاء شده توسط STZ، روند آيتيت آيويتوزيز

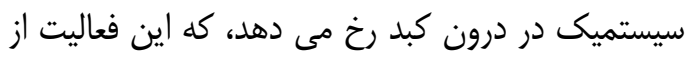
طريق مسيرهاى P53/ERK يا سيخنال هاى ملكولى دهي وساطت كننده P53 عمل مى كــند(T). مطالعات نشان مى دهد كه يكى از عوامل موثر در درمان بيمارى ها،

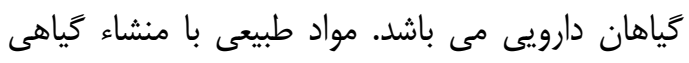

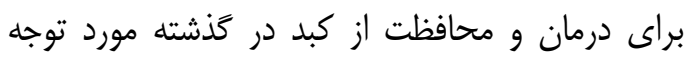
بوده است. گياهان دارويى در درمان سرطان، ديابت، آترواسكلروز و بيمارى هاى قلبى-عروقى نقش دارند. تركيبات فعال مانند فلاونوئيدها، مواد فنوليك و أنتى

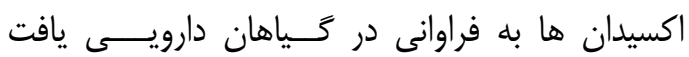
مى شوند(ه). فلاونوئيــدها و تركـيبات فنولى داراى فعاليت هاى بيولوزيكى متعدد از جمله توانايى خنثى

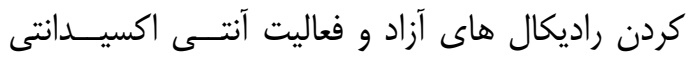

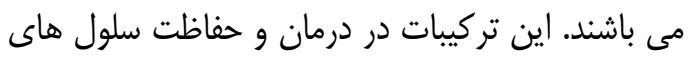

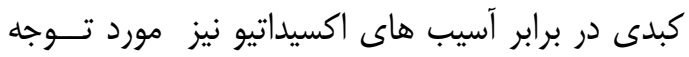
مى باشند(و). تركيبات فتوشيميايى زنجبيل شامل،

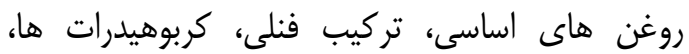

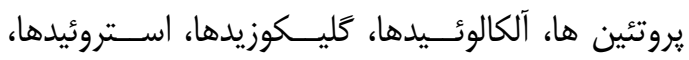


حيوانات به \& گروه تقسيم شدند: گروه كنترل، گروه

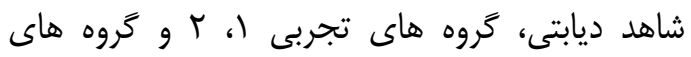

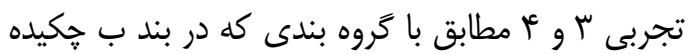

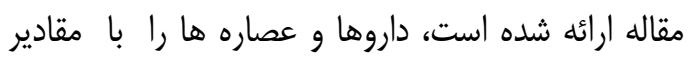
مختلف دريافت كردند. ميزان عصاره ها و مدت زمات زمان اندان آن با توجه به كارهاى قبلى صورت گرفته انتخاب

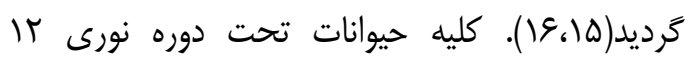

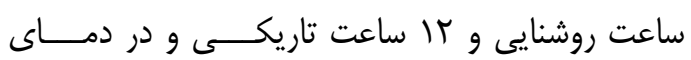

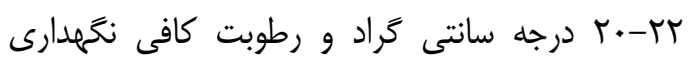
شدند. حيوانات به وسيله غذاهاى اســتانـــــارد تغذيه

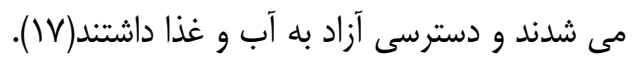
تهييه عصاره آبى زنجبيل: ريزوم تازه زنجبيل از از

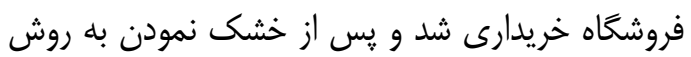

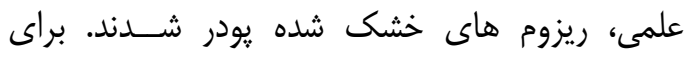
عصاره گيرى، يودر وزن شده در دستخاه يركولاتور قرار

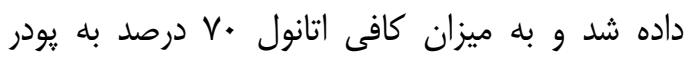
اضافه گشت. عصاره آبى يودر گياه زنجبيل طى مافى مدت ז ب ساعت در ظرفى به صورت قطره قطره جمع گرديد. در طول مدت عصاره گيرى در صورت پإيين آمدن

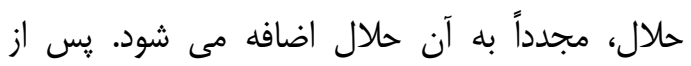

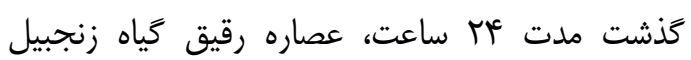
V. آماده مى شود و در ثايان حجم مصرفى اتانول

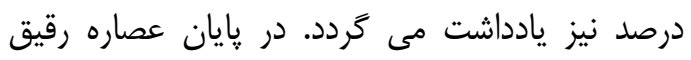

گياه به وسيله دستخاه روتارى تغليظ مى گرددد(9). نحوه تجويز دارو، روش خونتييرى، سنجش آنزيمى و بررسى هاى بافتى: ابتدا مقادير مختلف دارو

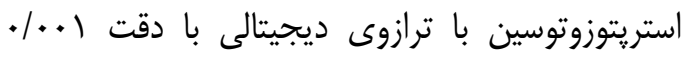

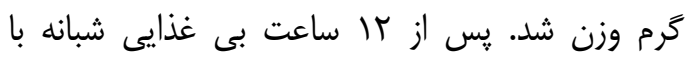

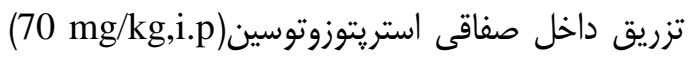
حل شده در سرم فيزيولوزى ديابت القاء شد(ها). ه روز يس از تزريق STZ، از نمونه هاى خونى تهيه شده

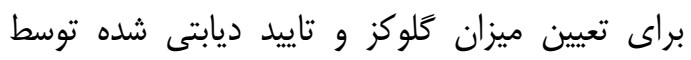

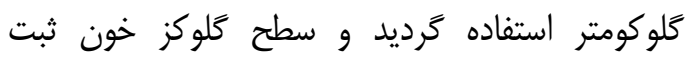

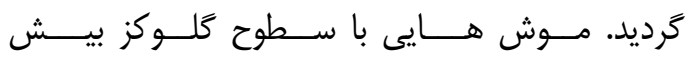

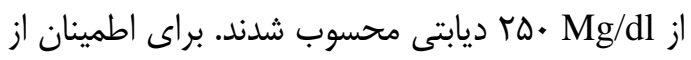

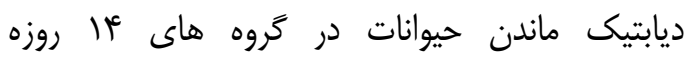
OGTT

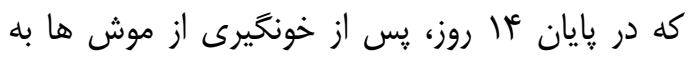

ميزان بروتئين هاى سرم و بافت كبدى را به طور قابل

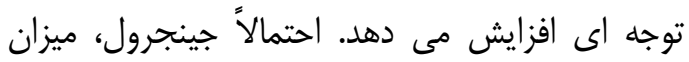

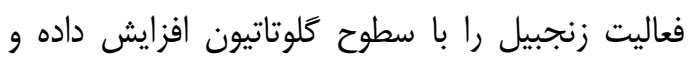

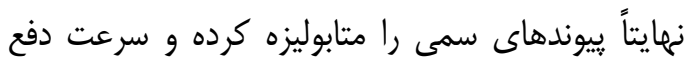

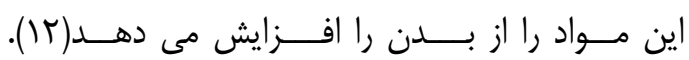

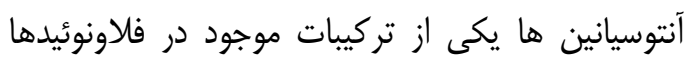

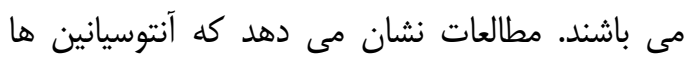

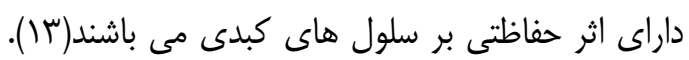

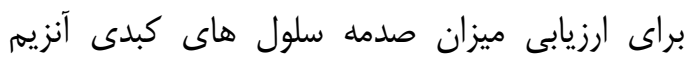

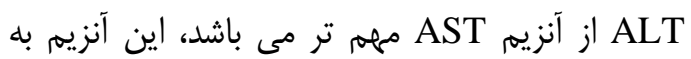

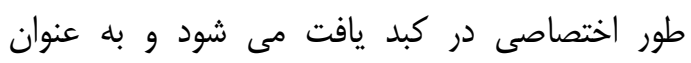
معيارى اختصاصى براى آسيب سلول هاى كبدى آنس است.

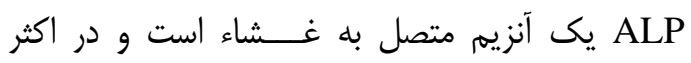

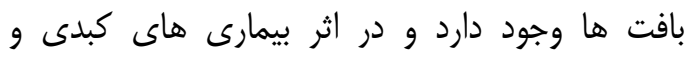

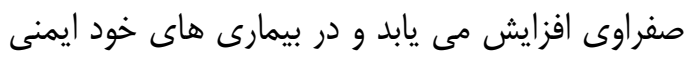

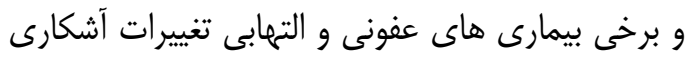

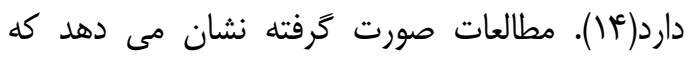

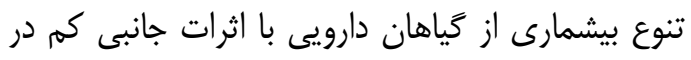

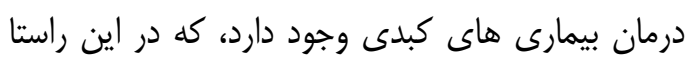

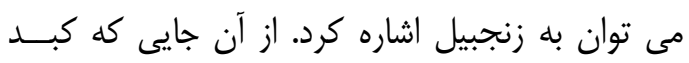

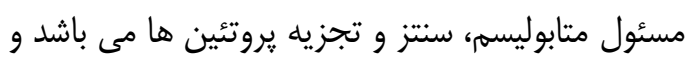

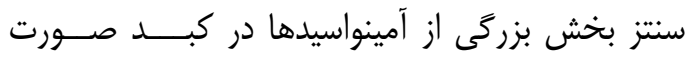

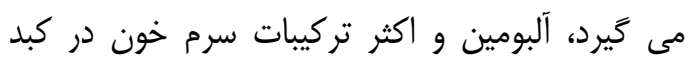

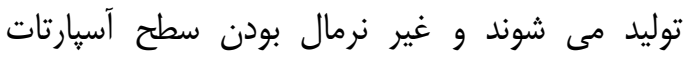

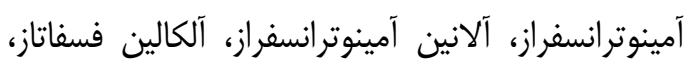

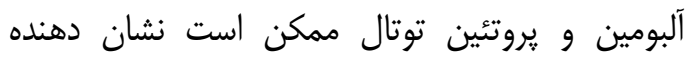

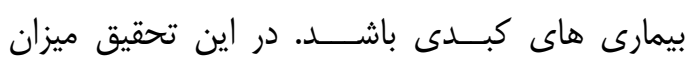

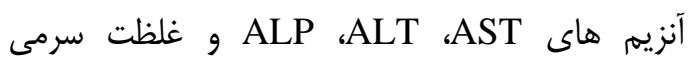

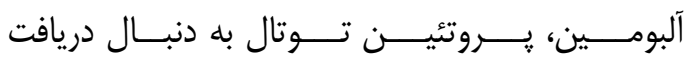

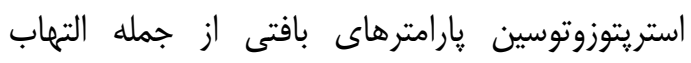

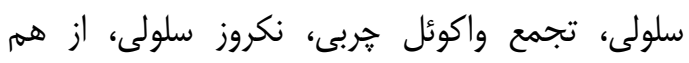

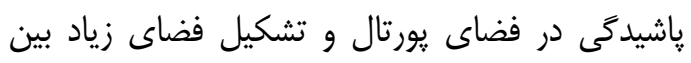

$$
\text { موادو وها بررسى شها. }
$$

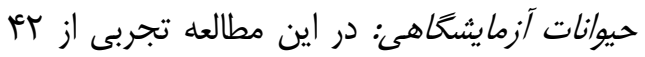

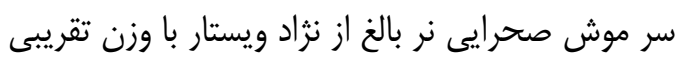

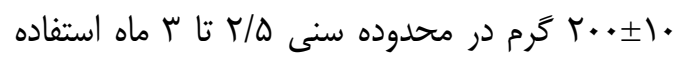
كرديد. 
براى مطالعات هيستوياتولوزيـــ با اســـفاده از

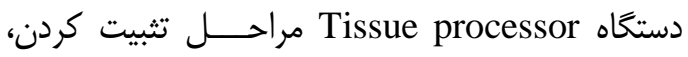

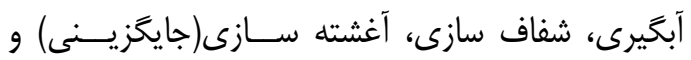

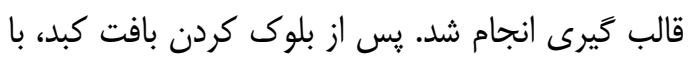

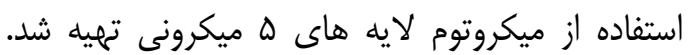
لام هاى تهيه شده با دو رنت هماتوكسيلين-ائوزين

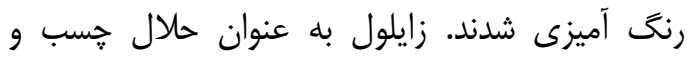

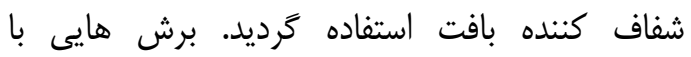

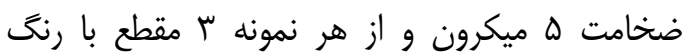

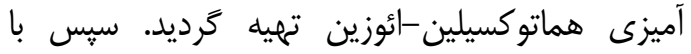
روش آسيب شناسى توسط يكى مقياس نيمه

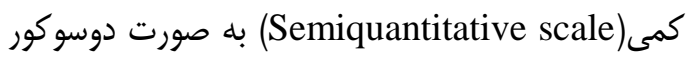
از نظر آسيب بررسى شدند. تغييرات هيستوياتولوزيك كبد در كروه هاى مختلف يارامترهايى از قبيل التهاب

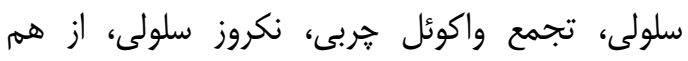

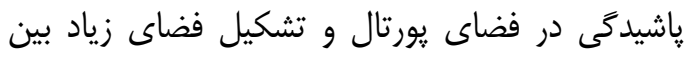

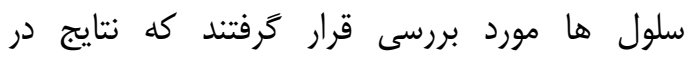
فتوميكروگراف هاى تهيه شده از بافت هاى كبد نشان

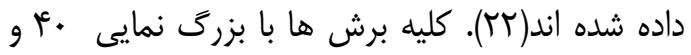

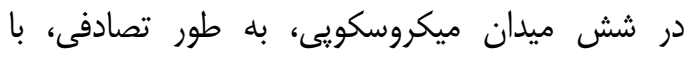

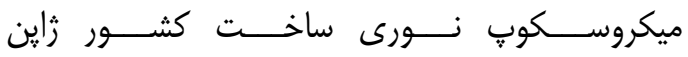
مدل نيكون(ECLIPSE E200) مشاهده كرديدند. از مناطق آسيب ديده تصاويرى با وضوح ينج مكاييكـسل

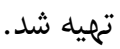

روش آمارى: جهت تجزيه و تحليل و آناليز داده ها

از برنامه نرم افزارى SPSS نسخه 1 استفاده شد. ابتدا اطلاعات به رايانه ها داده شد و آزمون آمارى ANOVA

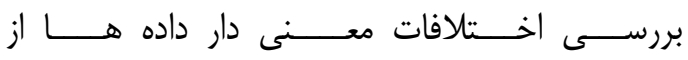
تست(Tukey-HSD) استفاده شد و معنادار بودن اختلاف ميانگين ها در سطح P>0.05 مورد بررسى

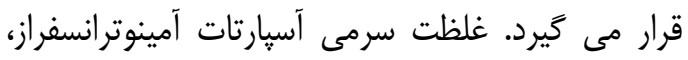
آلانين آمينوترانسفراز و آلكالين فسفاتاز، يروتئين توتال

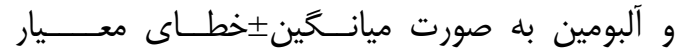
ارائه شد. (Mean \pm SEM)

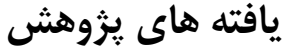

مقايسه ميانخين آنزيم AST در تروه شاهد ديابتى
هر حيوان gr/kg ا كلوكز به ازاى وزن بدن به طور

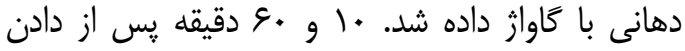

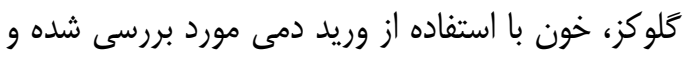

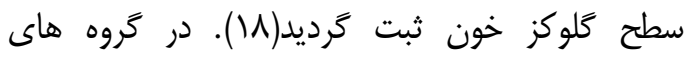

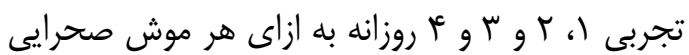

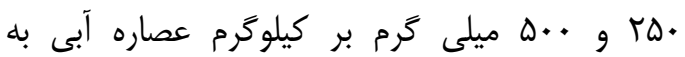
صورت كاواز خورانده شد. تجويز دارو روزانه بين ساعت

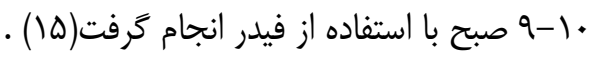
سيس در يايان دوره r ماهه آزمايش همه حيوانات

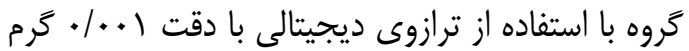

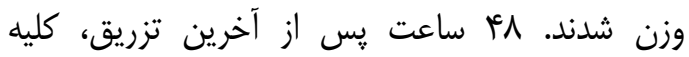

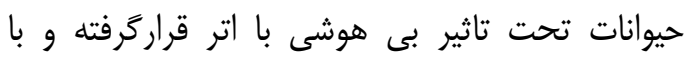

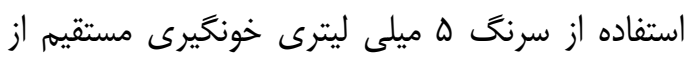
قلب انجام شد و از هر حيوان سّ تا ه ميلى ليتر خون إنى جمع آورى شد. نمونه هاى خونى به دست آمده خئن

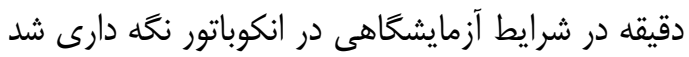
و سبس به مدت ها دقيقه با دور ... D در دقيقه سانتريفيوز شدند. سرم از لخته جدا شد و نمونه ها براى سنجش آنزيم ها و پارامترهاى بيوشيميايى در دماى ناي

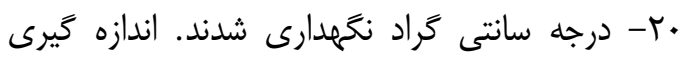
غلظت سرمى AST، ALT و ALP توسط دستخاه اوتــوآنالايزر مــــارك-ميرا(ساخت زإين) در آزمايشعاه تشخيص طبى با شيوه هاى خاص هر آنزيم انجام كرفت(19). غلظت سرمى فاكتورهاى مختلف توسط ناص شيوه هاى مناسب: آلبومين توسط شيوه Bromocresol biuret reaction end point اندازه گيرى شد. در اين روش يروتئين در محيط قليايى با يون هاى مس تشكيل كمبلكس لاجــوردى رنخ مى دهد. شدت رنخ ايجاد شده متناسب مقدار يروتئين در نمونه است(·r). يس از خونخيرى، با برش زدن

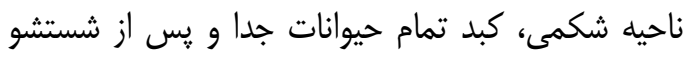

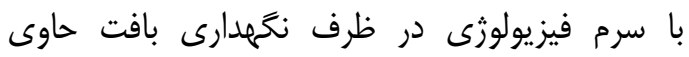
محلول فيكساتور فرمالين VA درصد قرار داده شدند. فرمالين ڤِ از كذشت عَ ساعت تعويض شد. بافت ها براى تهيه اسلايد به آزمايشحاه بافت شناسى ارسال

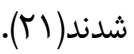


معنى دار در سطح PS0.05 نشان نداد. هم حنين در

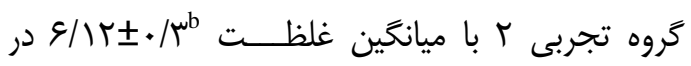

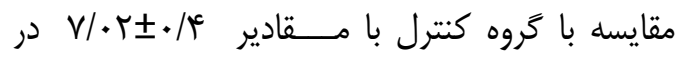
سطح P>0.05 كاهش معنى دار نشان داد، در حالى كه

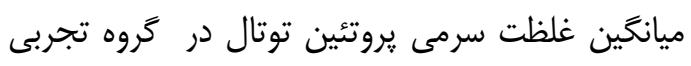

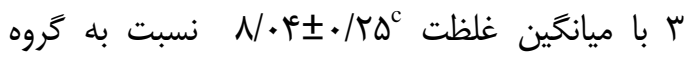

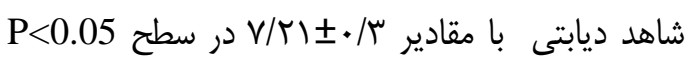
افزايش معنى دار نشان داد(جدول شماره ()). مقايسه

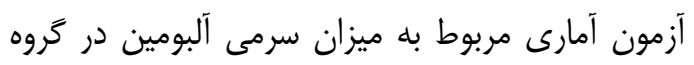

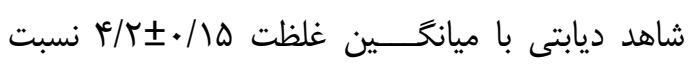

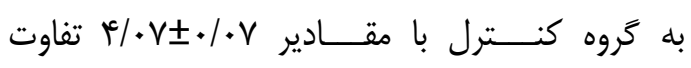
معنى دار در سطح P

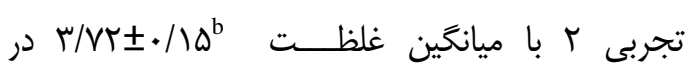

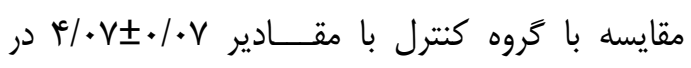
سطح Pl كاهش معنى دار نشان داد، در حالى كه

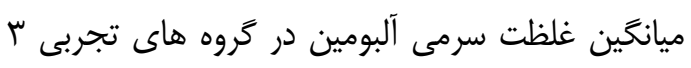

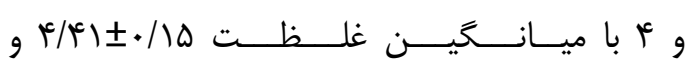
ه+|•

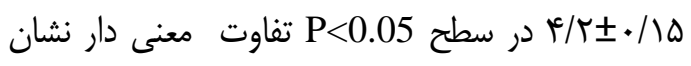

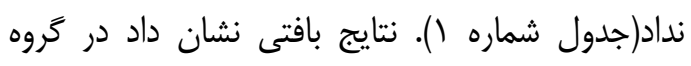
كنترل، هياتوسيت ها شكل طبيعى خود را حفظ كرده،

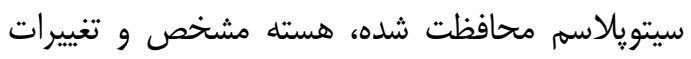
پاتولوزى خاصى در آن ديده نمى شود(شكل شماره ()).

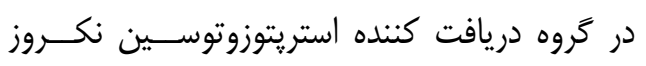

سلولى، از هم ياشيدكى در فضاى يورتال، هسته بزرى ديند و تشكيل فضاهاى زياد بين سلول ها، تورم شديد

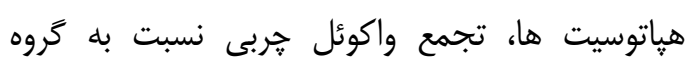

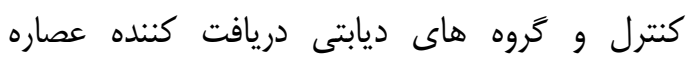

$$
\text { مشاهده شد(شكل شماره r). }
$$

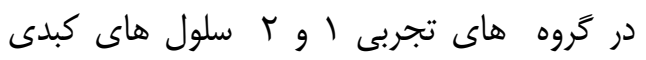

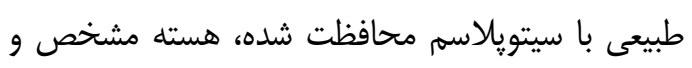

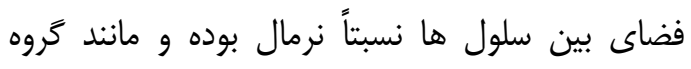

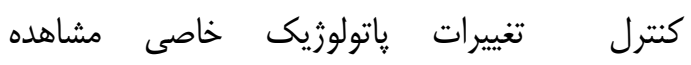

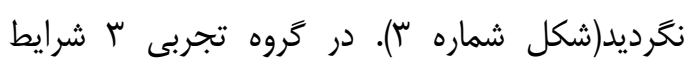

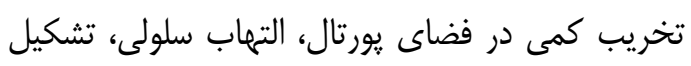

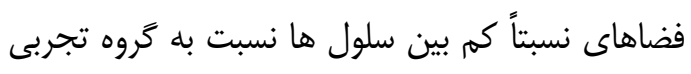

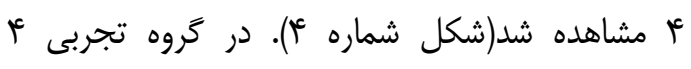

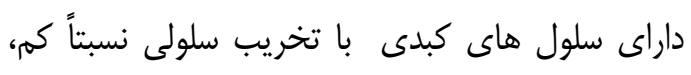

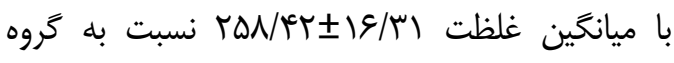
كنترل با مقادير

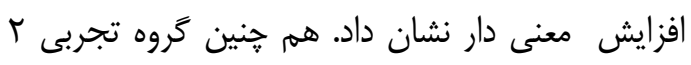

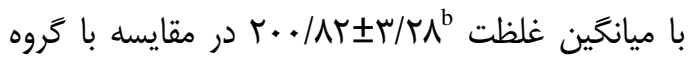
كنترل با مقادير افزايش معنى دار نشان داد، در حالى كه ميزان آنزيم AST شاهر

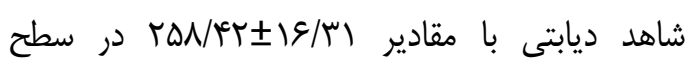
Pاهش معنى دار نشان داد(جدول شماره () ).

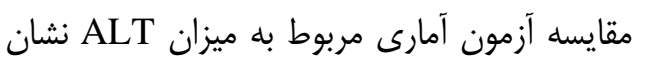

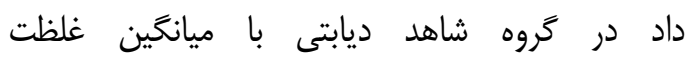

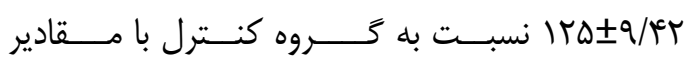
P<0.05 فز إيش معنى دار در سطح

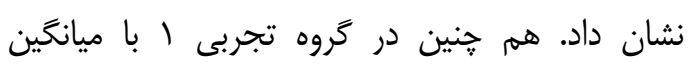

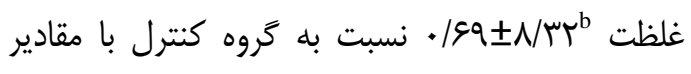

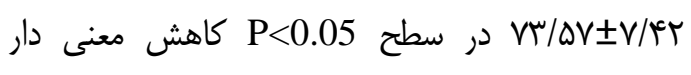

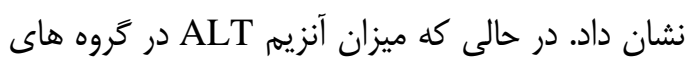

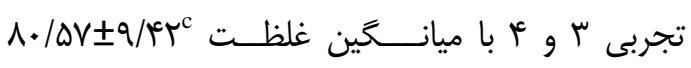

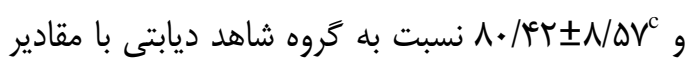

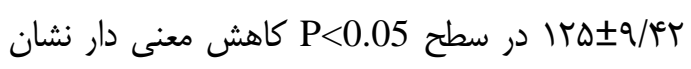
مى دهد(جدول شماره ()).

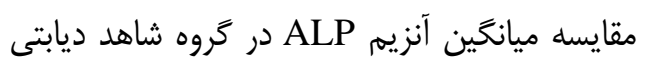
با ميانكين غلظت كروه كنترل با مقادير غلفين

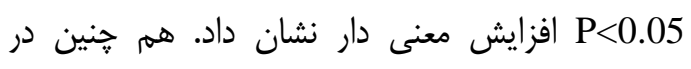
مروه تجربى ا با ميانگين غلظت

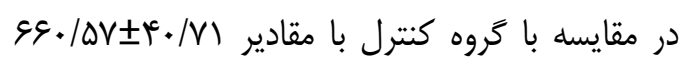

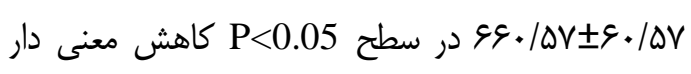

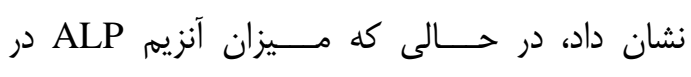

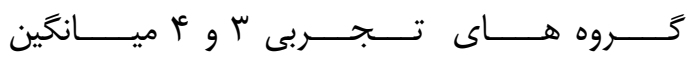
غـــــــــــــــ

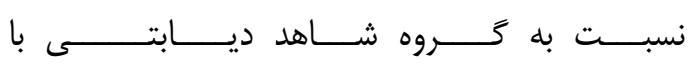

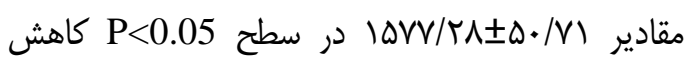
معنى دار نشان داد(جدول شماره ()). مقايسه آزمون

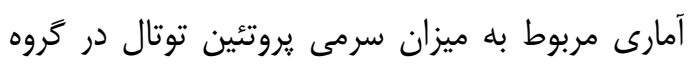

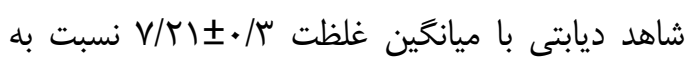

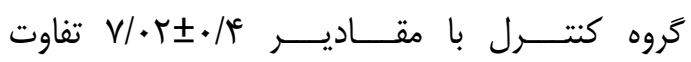


مشاهده نشد(شكل شماره ه).

فضاى بين سلول ها طبيعى و تغييرات ياتولوزى خاصى

\begin{tabular}{|c|c|c|c|c|c|}
\hline \multirow{3}{*}{ كروه ها } & \multirow{3}{*}{ AST(IU/Lit) } & \multirow{2}{*}{\multicolumn{2}{|c|}{ ميانكين و انحراف معيار }} & \multirow{3}{*}{ آلبومين(gr/dl) } & \multirow{3}{*}{ يروتئين توتال(gr/dl) } \\
\hline & & & & & \\
\hline & & ALT (IU/Lit) & ALP (IU/Lit) & & \\
\hline كنترل & $|r N / V| \pm \Delta / I V^{a}$ & $V \Psi / V \pm \Delta V / \propto r^{a}$ & $99 \cdot(\Delta V \pm r \cdot / V)^{a}$ & $r / \cdot V \pm \cdot / \cdot V$ & $V / \cdot r \pm \cdot / F$ \\
\hline شاهد ديابتى & rDN/ATEIE/TI & $1 T \Delta \pm Q /{ }^{2} T$ & $\mid \Delta V W / T \wedge \pm \Delta \cdot / V 1$ & $T / T \pm . / 1 Q$ & $V / T I \pm \cdot / r$ \\
\hline تجربى 1 & $\mid \Delta r / I V \pm \Delta V / \Delta V$ & $99 \pm N / \mu r^{b}$ & $\Delta \Delta q / / I^{a} \pm r / / F^{b}$ & $r / T \Lambda \pm \cdot / r$ & $V / \& \Delta \pm \cdot / \mathcal{G}$ \\
\hline تجربى r & $r \cdots / r \Lambda \pm r / r \Lambda^{b}$ & $\Lambda T / F T \pm T / T I$ & $V T \cdot / 1 f \pm q \cdot / 1 f$ & $r / V T \pm \cdot / / Q^{b}$ & $q / 1 r \pm \cdot / \mu^{b}$ \\
\hline تجربى " & $|Q| / F r q \pm . / T \Lambda^{c}$ & $\Lambda \cdot / \Delta V \pm q / \kappa^{*} T^{c}$ & $G V \Delta / r \Lambda \pm Y \Phi \Delta / V)^{c}$ & $F / F I \pm . / 1 Q$ & $N \cdot F \pm \cdot / r \omega^{c}$ \\
\hline تجربى f & $19 V / r+ \pm \Delta V / I F$ & $\Lambda \cdot / F Y \pm N / \Delta V^{c}$ & $V^{\mu} \pm \Psi T^{\prime} / r \Lambda^{c}$ & $F / r \mid \pm .1 \cdot \Delta$ & $V / V I \pm \cdot / T \Delta$ \\
\hline
\end{tabular}

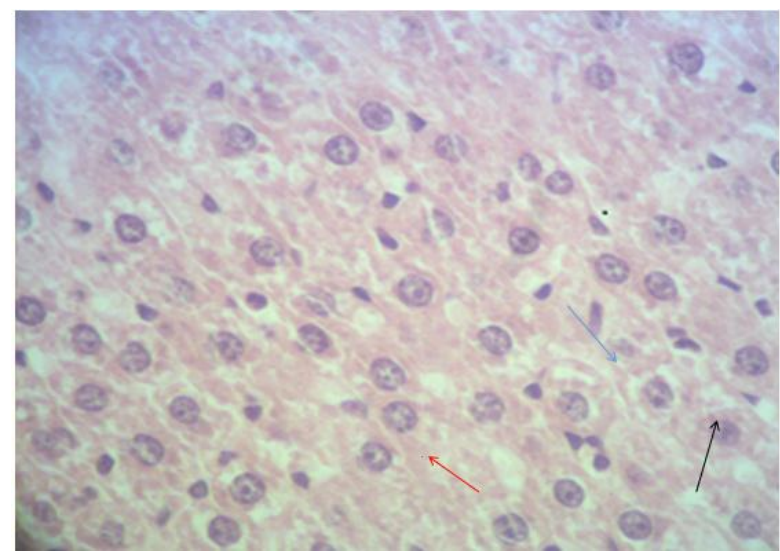

شكل شماره (. بافت كبد در تروه كنترل، سلول ها داراى اندازه طبيعى(فلش مشكى)، هسته طبيعى(فلش قرمز)

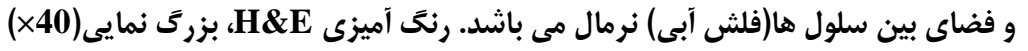

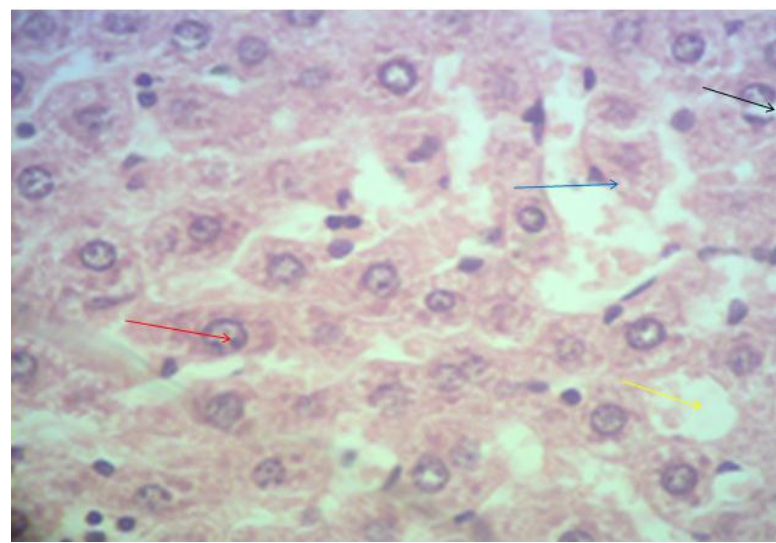

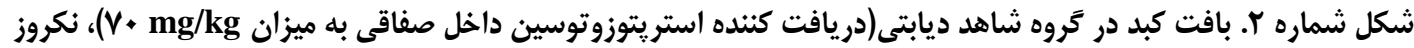

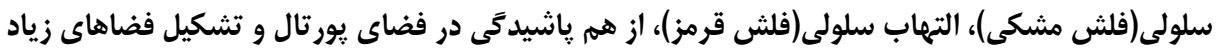

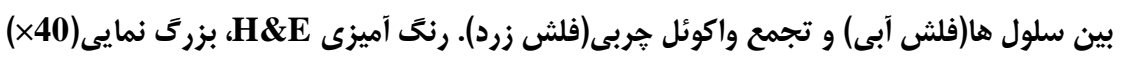




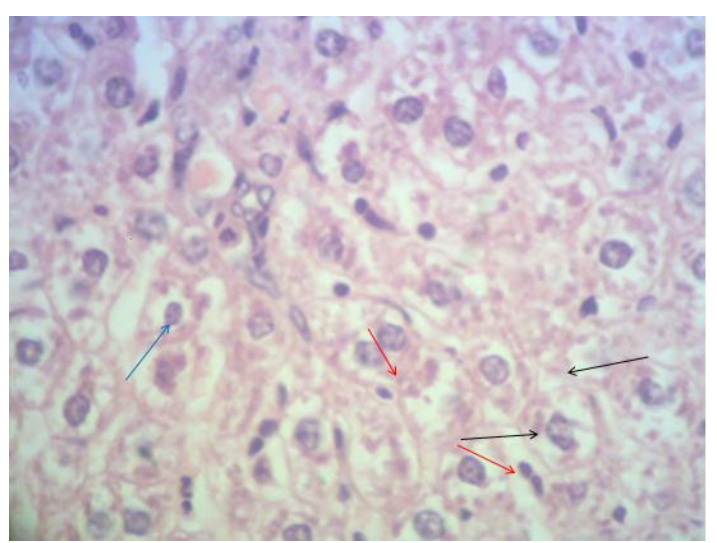

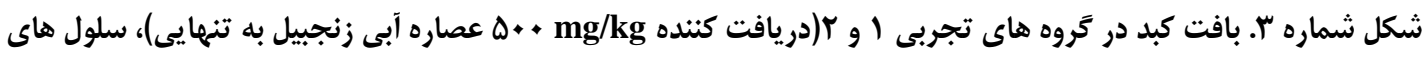

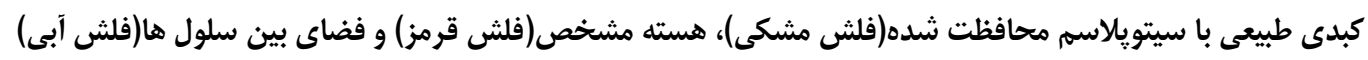

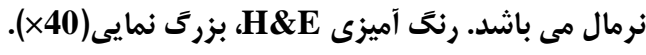

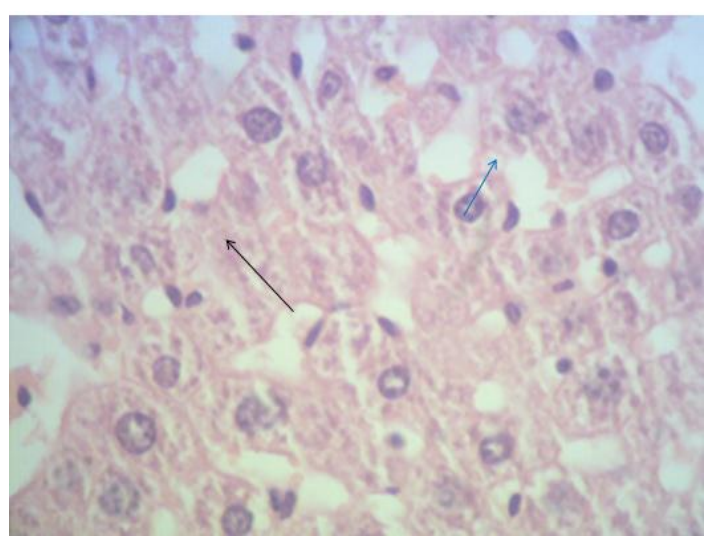

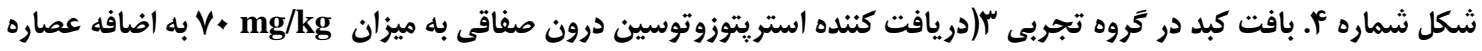

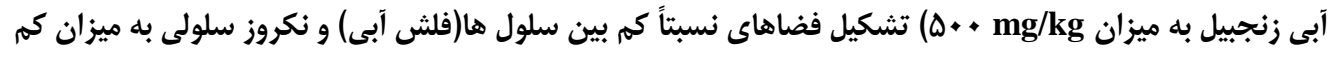

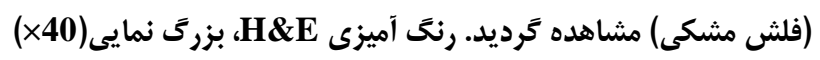

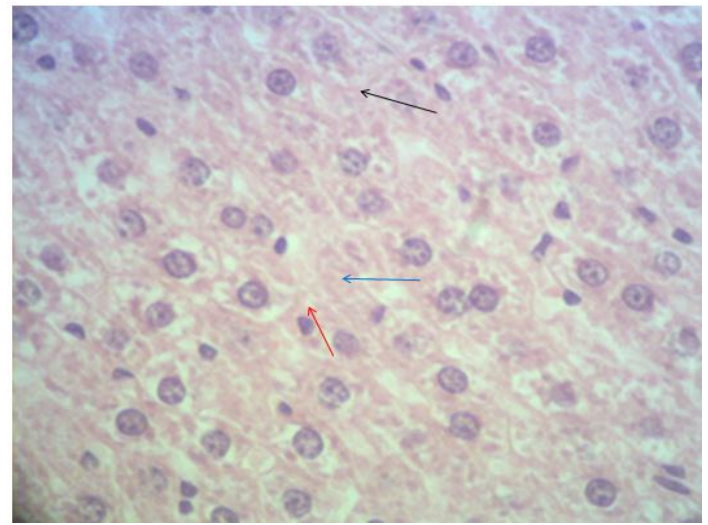

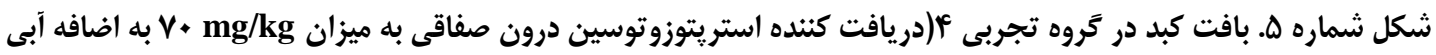

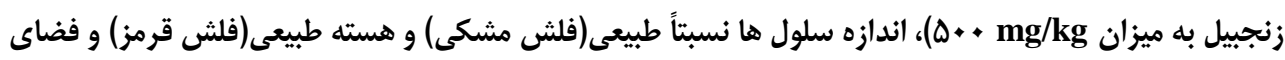

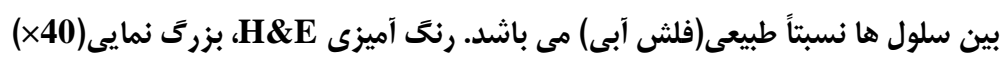


زنجبيل با ميزان mg/kg . مه اثر قابل توجه اى در كاهش التهاب نشان مى دهد(TV).

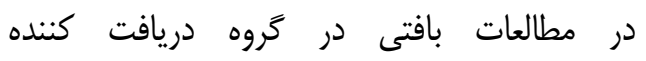

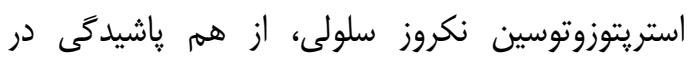
فضاى يورتال، هسته بزرى و تشكيل فضاهاى زياد بين سلول ها، تورم شديد هياتوسيت ها، تجمع واكوئل جربى نسبت به گروه كنترل مشاهده شد(شكل شماره

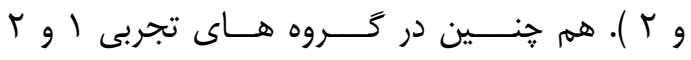
سلول هاى كبدى طبيعى با سيتو يلاسم محافظت شده،

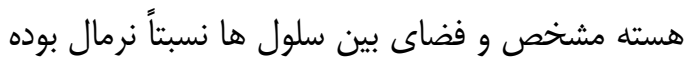

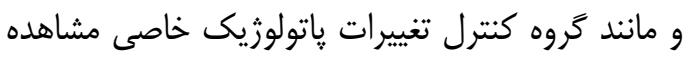

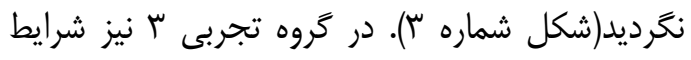

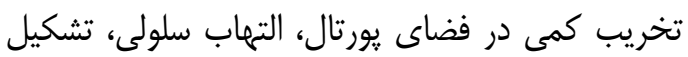

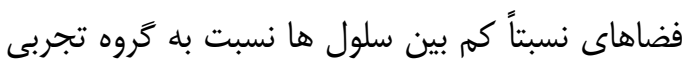

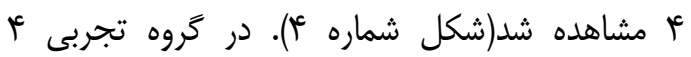
سلول هاى كبدى با تخريب سلولى نسبتاً كم، فضاى

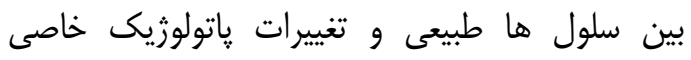
مشاهده نشد(شكل شماره ه).

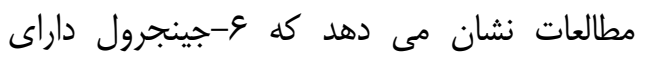

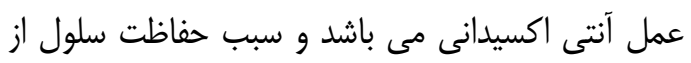

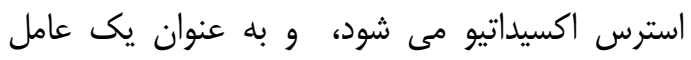

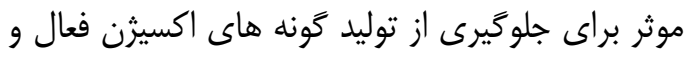

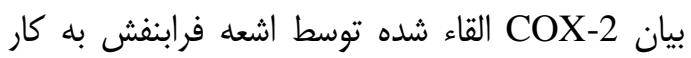

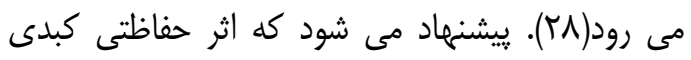

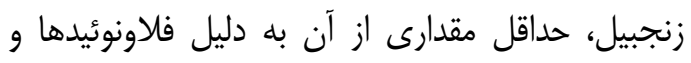

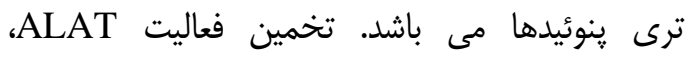

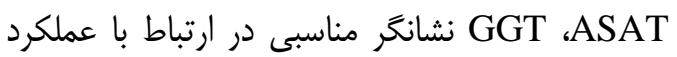

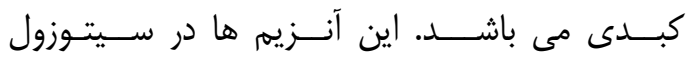

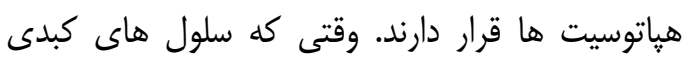

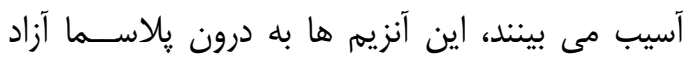

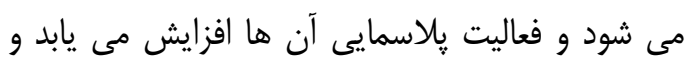

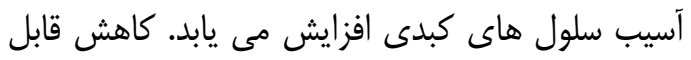

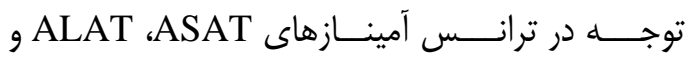
فعاليت هاى GGT در ارتباط با اثرات حفاظت كبدى

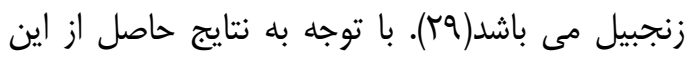

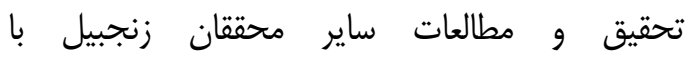

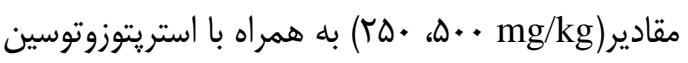
باعث برَشت AST، ALT و ALP به حد طبيعى شد.

\section{بحث و نتيجٍه كيرى}

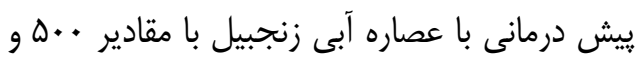
ra. mg/kg

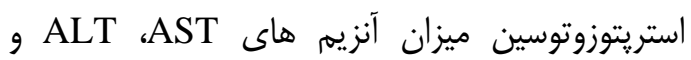

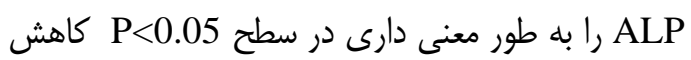
داد، در حالى كه ميزان آنزيم هاى ALT و ALP در در در كروه هاى دريافت كننده زنجبيل نسبت به گروه كنترل كاهش درئ معنى دار در سطح P>0.05 نشان داد(جدول شماره ().

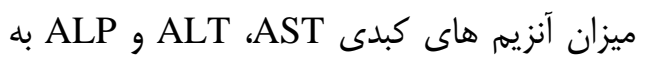
صورت معنى دارى به دنبال دريافت استريتوزوتوسين

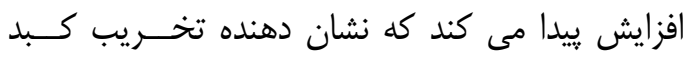

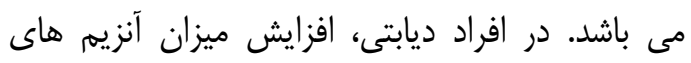

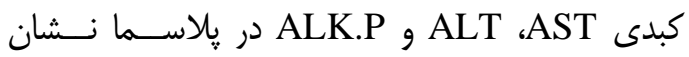

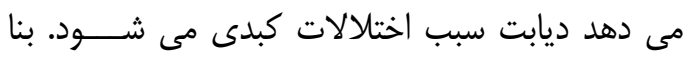

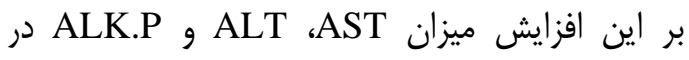

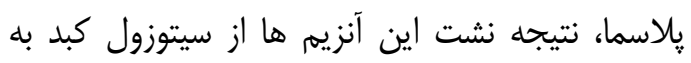

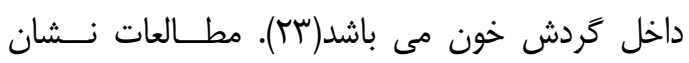

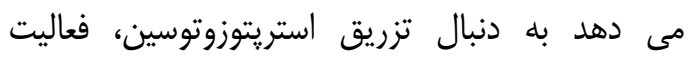

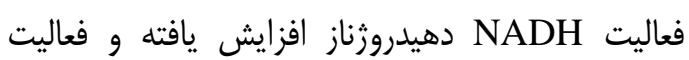
سيتوكروم c اكسيداز در زنجيره تنفسى ميتوكندريايى

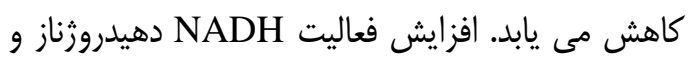

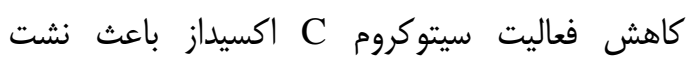
الكترون ها از غشاى داخلى ميتوكندرى و افزايش توليد

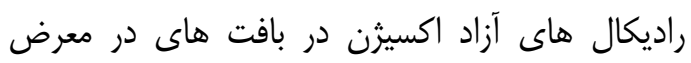
STZ مطالعات نشان مى دهد در بيماران ديابتى، عملكرد

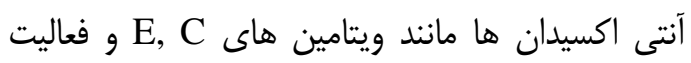

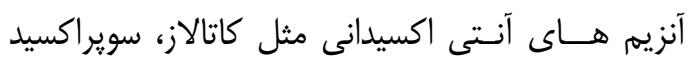

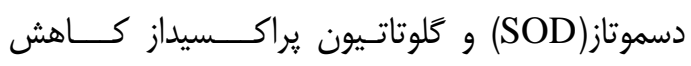

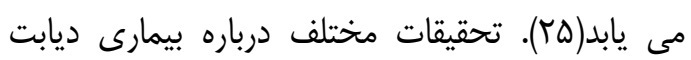

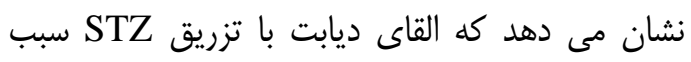
افزايش معنى دارى در سطح سرمى آنزيم هاى عملكرد

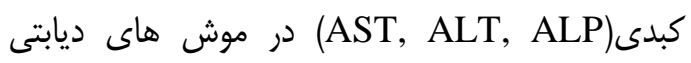
نسبت به گروه نرمال مى گرددد(

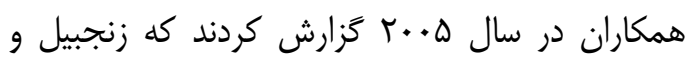

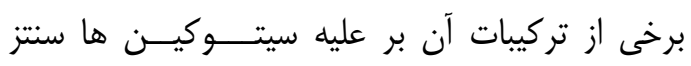

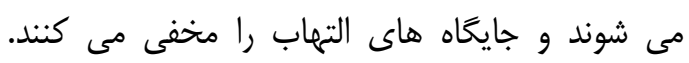


افزايش تدريجى غلظت آلبومين و يروتئين كل مشاهده

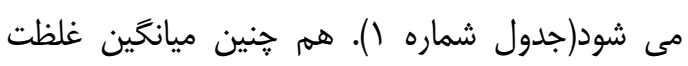

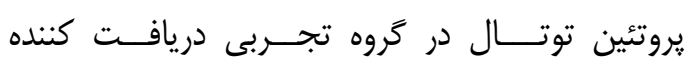

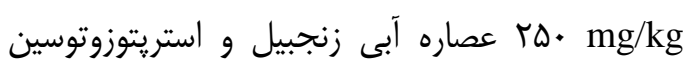
نسبت به گَروه شاهد ديابتى افزايش معنى دار دار در سطح

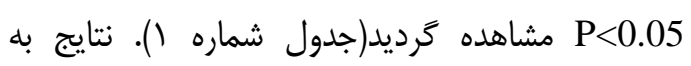
دست آمده از مقادير ro . mg/kg عصاره آبى زنجبيل و استريتوزوتوسين نشان مى دهد كه اين داراى اثرات موثرى بر ميزان يروتئين توتال مى باشد. مطالعات دهات

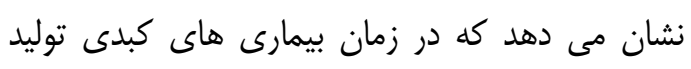
آلبومين كاهش مى يابد. از آن جايى كه كبد در در سنتز

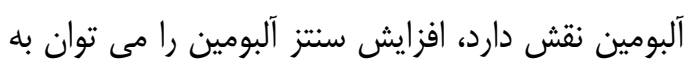

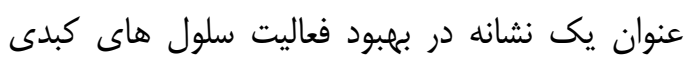

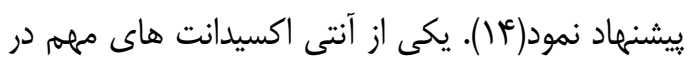

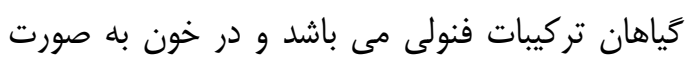

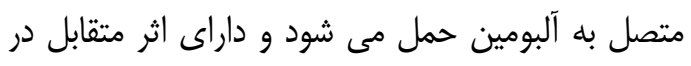

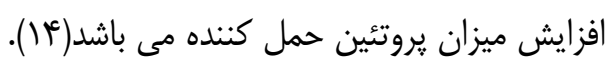

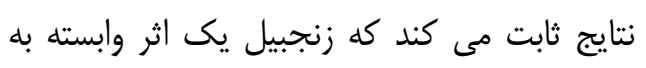

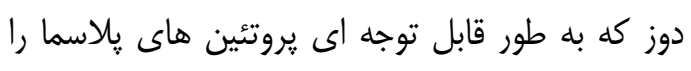

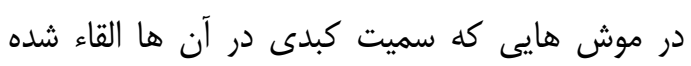

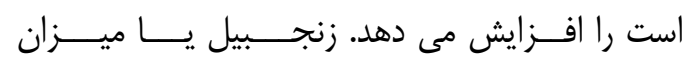

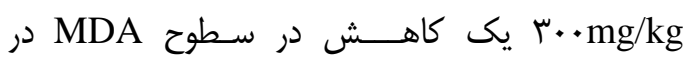
بافت هاى كبدى را نشان مى دهد (Y) (I).

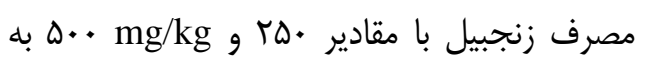

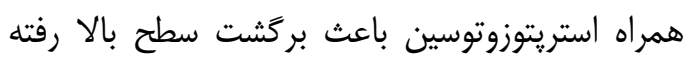

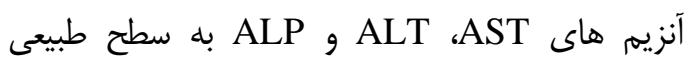
(تروه كنترل) شد كه به علت خاصيت آنتى اكسيدانتى

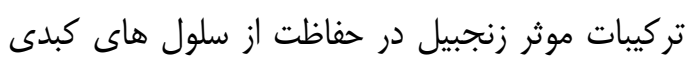
در مقابل استرس اكسيداتيو مى باشد. هم جنين عصاره

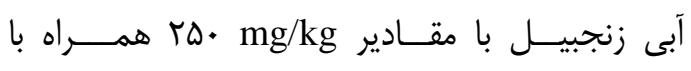

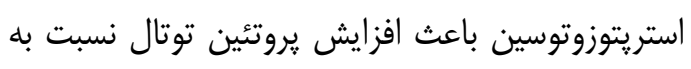

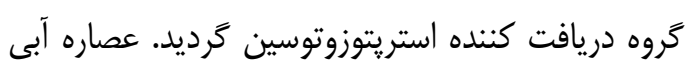
زنجبيل مى تواند توسط مكانيسم هاى مختلف موجب اثرات حفاظتى بر تغييرات فاكتورهاى شيميايى مرتبط بان بان كبد القاء شده توسط استريتوزوتوسين كرددات ييشنهاد مى كردد در مطالعات آتى اثر عصاره زنجبيل بر عوارض كبدى ناشى از ديخر سموم القاء كننده ديابت در موش هاى صحر ايى مورد مطالعه قرار

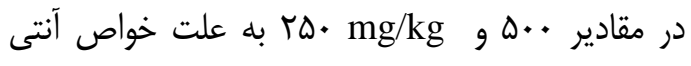
اكسيدانى تركيبات زنجبيل باعث محافظت سلول هاى

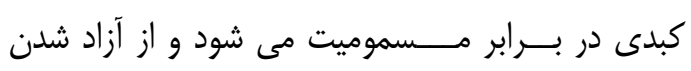

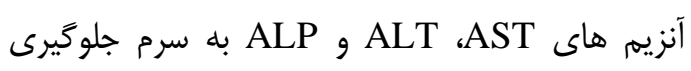

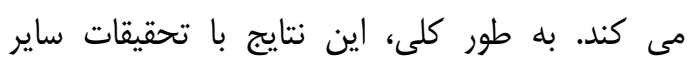

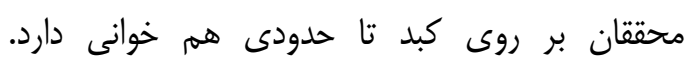
مطالعات نشان مى دهد عصاره اتانولى ريزوم زنجبيل

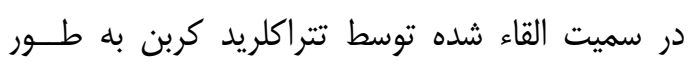

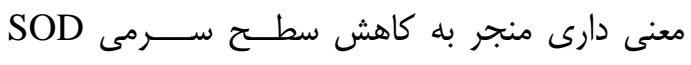

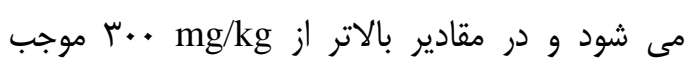

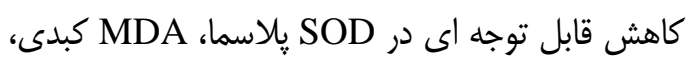

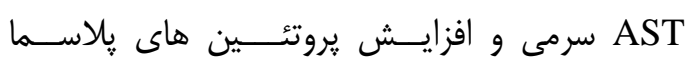

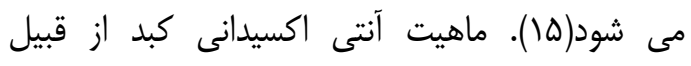
فعاليت هاى SOD ، طور قابل توجه اى در موش هايى كه با استامينوفن

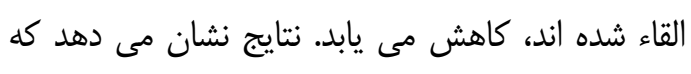

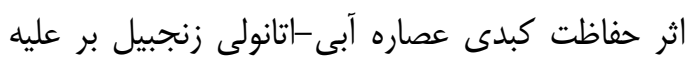

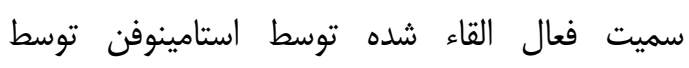
جلوگيرى از كاهش آنتى اكسيدان هاى كبدى و يا در ترسط

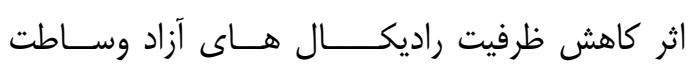

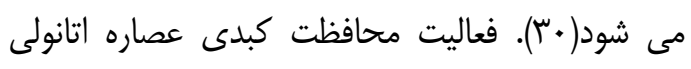

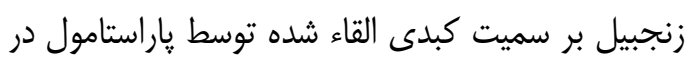
موش هاى صحرايى گزارش شده است. عصاره زنجبيل به طور قابل توجه اى منجر به كاهش آنزيم كلوتامات

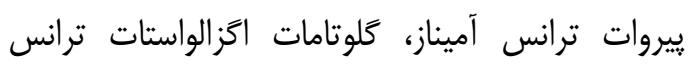

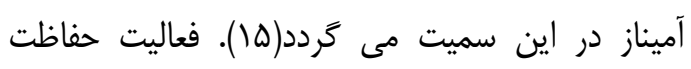

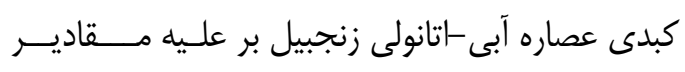

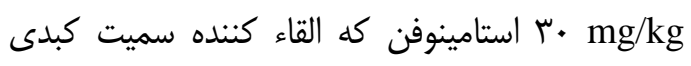

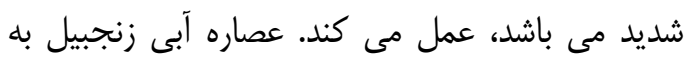

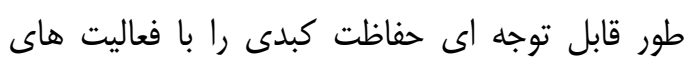

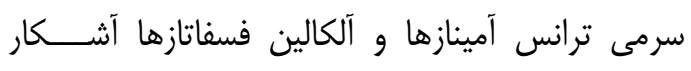
مى سازد(·r). مقايسه نتايج آزمون آمارى مربوط بـ فيه فعاليت يروتئين توتال و آلبومين در گروه تجربى ازئ دريافت كننده مني ار معنى دار نشان مى دهد، كه در واقع نشان دهنده اين مطلب است كه اين مقدار از زنجبيل اثراتى منفى بر دهر دار دان دهن روى آلبومين و يروتئين كل دارد. در دوزهاى كمتر إنى 
فنولى(Gingerol، Shoagol و و Gingerdion) و

آنتوســيانين ها باعــث كاهـش سميت كبدى ناشى

$$
\text { استريتوزوتوسين گرديد. }
$$$$
\text { سياسگَزارى }
$$

بديــن وســيله از مســــولين محسـترم دانشــاه

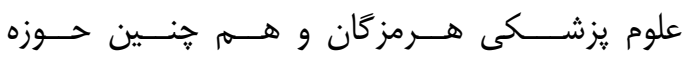

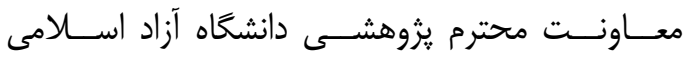

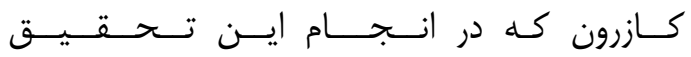

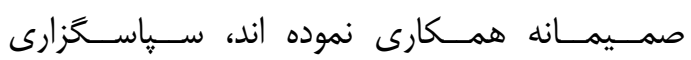

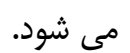

\section{References}

1. Raju SBG, Battu RG, Manju latha YB, Srinivas K. Anti hepatotoxic activity of smilax china roots on CCL4 induced hepatic damage in rats. Int $\mathrm{J}$ Pharm Pharm sci 2012 ; 4:494-6.

2. Frances DE, Ronco MT, Monti JA, Ingaramo PI. Hyperglycemia induces apoptosis in rat liver through the increase of hydroxyl radical new insights into the insulin effect. J Endocrinol 2010 ;205: 187 200.

3. Ahangarpour A, Zamaneh H. T, Jabari A, Malekshahi Nia H, Heidari H. Antidiabetic and hypolipidemic effects of Dorema aucheri hydroalcoholic leave extract in Streptozotocin nicotinamide induced type 2 diabetes in male rats. Iranian $\mathbf{J}$ Basic Med Sci $2014 ; 10: 808-14$.

4. Anwar MM, Abdelraheim MA. Oxidative stress in Streptozotocin induced diabetic Rats effecs of garlic oil and melatonin. Cam Biochem Physi 2003;135: 539-47.

5. Bahmani M, Saki K, Shahsavari S . Identification of medicinal plants effective in infectious diseases in Urmia, northwest of Iran. Asi Paci J Trop Biomed 2015; 5: 858-64.

6. Anbarasu C, Rajkapoor B, Bhat KS, Giridharan J, Amuthan A A, Satish K. Protective effects of pisonia aculeata on thioacetamide induced hepatotoxicity in rats. Pac J Trop Biomed 2012;2:511-515.

7. Adel P, Prakash R. Chemical composition and antioxidant operties of ginger root zingiber officinale. J Med Plants Res 2010 ; 4:2674-9.

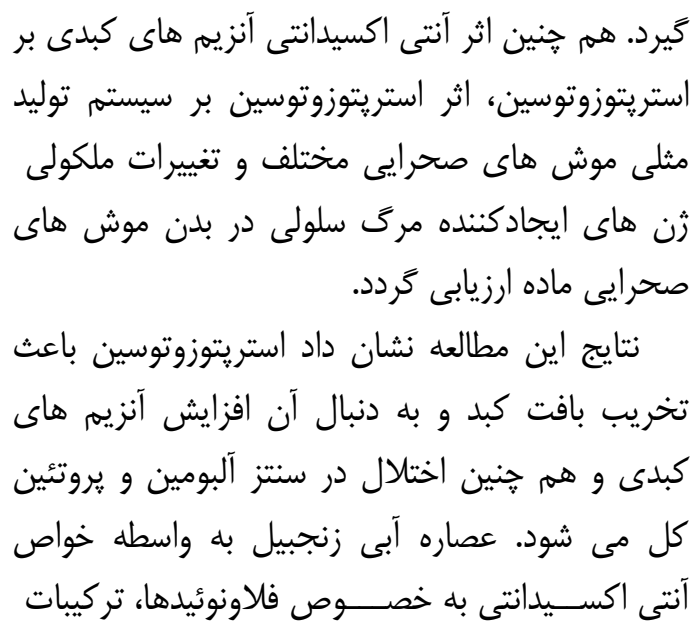

8. Rehman A. Zingiber officinale Roscoe pharmacological activity. J Med Plants Rese 2011;5: 344-8.

9. Dadfar F, Hosseini SE, Bahaoddini A. [A review of phytochemical, pharmacological and physiological properties of ginger zingiber officinale]. J Clin Exce 2014; 3: 72-86. (Persian)

10. Gharib S, Bahaoddini A, Vatanparast J, Moein M. [Effect of alcoholic extract of ginger zingiber officinale roscoe on mechanical activity of isolated jejunum of male Rat]. Phys Pharm 2015 ;18:406-415. (Persian)

11. Hasanin P, Gamar A . [Effect of zingiber officinalis rosethanol extract on Hyssine induced antinociceptive activity in male Rats.] J Med Plants 2014;2 :1729.(Persian)

12. Rahuman AA, Gopalakrishnan G. Mosquito larvicidal activity of isolated compounds from the rhizome of Zingiber officinale. Phyto Res 2008;22:1035-9.

13. Salmanian H, Sadeghi Mahoonak AR, Alami M, Ghorbani M. Evaluation of total phenolic flavonoid anthocyanin compounds antibacterial and antioxidant activity of hawthorn Crataegus elbursensis fruit acetonic extract. J Raf Uni Med Sci 2014; 13: 53-66.

14. Afrasiabie M, Mokhtari M. [Effect of Dianthus carryophyllu extract on the induced hepatotoxicity by Gentamicin in Wistar Rats]. J Gorgan Uni Med Sci 2016; 18:22-9. (Persian)

15. Norina A, Nurzakiah MS . Protective effect of the ethanol extract of Zingiber 
officinale roscoe on paracetamol induced hepatotoxicity in Rats. J Sains Kes Mala 2004; 2: 85-95.

16. Gajdosik A, Gajdosikova A, Stefek M, Navarova J, Hozova R. Streptozotocininduced experimental diabetes in male wistar Rats. Gen Physiol Biophys 1999; 18:54-62.

17. Ashraf H, Zare S, Farnad N. [The effect of aqueous extract of barberry fruit on liver damage in streptozotocin induced diabetic Rats]. J Shahrekord Uni Med Sci 2014; 15: 1-9.(Persian)

18.Pouraboli I, Nazari S, Ranjbar B, Shariati M, KargarJahromi $\mathrm{H}$. [Antihyperglycemic and antihyperlipidemic effects of Daucuscarota ssp. sativum seeds extract in diabetic Rats]. J Babol Uni Med Sci 2014;16: 33-40. (Persian)

19. Alamin, Zainab M. Anti diabetic and hypolipidaemic properties of ginger Zingiber officinalein Streptozotocin induced diabetic Rats. British J Nut 2006;96: 660-6..

20. Mostafavi Pour Z, Zal F, Monabati, Vessal M. Protective effects of a combination of quercetin and vitamin $\mathrm{E}$ gainst cyclosporine $\mathrm{A}$ induced oxidative stress and hepatotoxicity in Rats. Hepathol Res2008;38:385-92.

21. Fatehi F, Taghavi NM, Hasanshahi GH, Hoseini J, Jamali Z. Evaluation of effects of angi-pars on kidney brain and liver tissue of chronic diabetic Rats. J Rafsanjan Uni Med Scie 2013;12:185-94.

22. Juhua CH, Georgetipoe L, Emily C. Green tea polyphenols prevent toxin- induced hepatotoxicity in mice by down regulating inducible nitric oxide derived prooxidants. Am J Clin Nutr 2004; 80: 74251.

23. Navarro CM, Mantilla PM, Martin A, Jimene ZJ, Utrilla PM. Free radicals scavenger and antihepatoxic activity of Rosmarinus. Planta Med 1993; 59: 312-4 . 24. Haider R, Subbuswamy K, Prabu M.A, Narayan G. Impaired mitochondrial respiratory functions and oxidative stress in Streptozotocin induced diabetic Rats. Inter J Mol Sci 2011; 12: 3133-47.

25. Ken J.The Antidiabetic activity of Aloevera. Am Diabetes 2004; 2:13.

26. Eidi A, Eidi M, Esmaili E. Antidiabetic effect of garlic Allium sativum L. in normal and Streptozotocin induced diabetic Rats. Phytomed 2006;13:624-29.

27. Thomson, Alqattan. The use of ginger Zingiber officinale rosc as a potential anti inflammatory and antithrombotic agent. Pros Leu Ess Fat Acids 2002; 67: 475-8.

28.Kim JK, Kim Y. Kim TY. Gingerol prevents UVB induced Ros production and cox-2 expression invitro and invivo. Free Rad Res 2007; 41:603-14.

29. Eman GE. Helal W. Effect of Zingiber officinale on fatty liver induced by oxytetracycline in albino Rats. Egyptian $\mathbf{J}$ Hos Med2012 ;46: 26-42.

30. Ajith. TA, Hema U. Zingiber officinale Roscoe prevents acetaminophen-induced acute hepatotoxicity by enhancing hepatic antioxidant status. Food Chem Tox2007;45; 2267-72 . 


\title{
Effects of Ginger (Zingiber Officinale) Aqueous Extract on the Levels of Hepatic Enzymes, Biochemical Parameters, and Histological Changes in Male Wistar Strain Rats Following Treatment of Streptozotocin
}

\author{
Shahrivar $T^{1}$, Mokhtari $M^{* 1}$, Alipour $V^{2}$
}

(Received: September 1, 2017

Accepted: January 9, 2018)

\begin{abstract}
Introduction: Diabetes induces leakage of hepatic enzymes from cytosol into the circulation and increases the plasma levels of these enzymes. In this study, the impacts of ginger (Zingiber Officinale) aqueous extract on the levels of liver enzymes, biochemical parameters, and histological changes in male rats were assessed following induction of diabetes by Streptozotocin.
\end{abstract}

Materials \& methods: 42 male Wistar rats were divided into 6 groups: the control (left untreated), Diabetic control received 70 $\mathrm{mg} / \mathrm{kg}$ Streptozotocin once at the beginning of the experiment; the experimental groups 1 and 2 daily received 250 and $500 \mathrm{mg} / \mathrm{kg}$ ginger aqueous extract respectively; the experimental groups 3 and 4 first received Streptozotocin once, and then a daily dose of 250 and $500 \mathrm{mg} / \mathrm{kg}$ extract. Oral administration of aqueous extract continued over a period of two months. 48 hours after the last administration blood samples were prepared and used for measurement of aspartate aminotransferase (AST), alanine aminotransferase (ALT), alkaline phosphatase (ALP), and the serum levels of albumin and total protein. Also, hepatic histological study was carried out by hematoxylin-eosin staining method.

Findings: The serum levels of AST, ALT, and ALK enzymes in diabetic control group (recipient of $70 \mathrm{mg} / \mathrm{kg}$ Streptozotocin) and the AST enzyme concentration in experimental group 2 (recipient of 500 $\mathrm{mg} / \mathrm{kg}$ Ginger extract alone) increased significantly compared to the control group $(p<0.05)$. In contrast, the levels of ALT and ALP enzymes declined significantly in experimental group 1 (recipient of $250 \mathrm{mg} / \mathrm{kg}$ extract alone) relative to the control p $(<0.05)$. Serum concentrations of total protein and albumin reduced significantly in the experimental group 2 in comparison with the control group. Also, In experimental groups 3 and 4 (recipient of 250 and $500 \mathrm{mg} / \mathrm{kg}$ Ginger extract and Streptozotocin) relative to the diabetic control group, the levels of AST, ALT and ALP indicated a significant reduction, while the concentration of total proteins increased significantly in experimental Group 3 ( $\mathrm{p}<$ $0.05)$. Finally, histological study revealed cellular necrosis, cellular inflammation, and vacuolar fat accumulation, disintegration of Portal spaces and formation of large intercellular spaces in diabetic control relative to the control group. Such disorders were less significant in groups receiving Streptozotocin along with $500 \mathrm{mg} / \mathrm{kg}$ doses of extract compared to the group receiving Streptozotocin alone.

Discussion \& conclusions: Due to the presence of compounds such as gingerol, shoagol, and anthocyanins, ginger aqueous extract can possibly reduce hepatic toxicity caused by Streptozotocin and improve the serum levels of liver enzymes.

Keywords: Ginger, Streptozotocin, AST, ALT, ALP, Biochemical parameters, Rat

1.Dept of Biology, Faculty of Sciences, Islamic azad University, Kazerun Branch, Kazerun, Iran

2. Dept of Environmental Health, Faculty of Environmental Health, Hormozgan University of Medical Sciences, Hormozgan, Iran

* Corresponding author Email: M. Mokhtari246@yahoo.com 